\title{
Initial Reactions in the Oxidation of Anthracene by Cunninghamella elegans
}

\author{
By CARL E. CERNIGLIA \\ National Center for Toxicological Research, Food and Drug Administration, Jefferson, \\ Arkansas 72079, U.S.A.
}

(Received 12 January 1982)

\begin{abstract}
Cunninghamella elegans oxidized anthracene predominantly to trans-1,2-dihydroxy-1,2-dihydroanthracene and 1-anthryl sulphate. In addition, several unidentified metabolites were produced. The major compounds formed were isolated by TLC and HPLC, and identified by their UV-visible absorption and mass spectra. Experiments with $\left[9-{ }^{14} \mathrm{C}\right]$ anthracene indicated that the total amount of anthracene metabolized increased from $2.0 \%$ at $2 \mathrm{~h}$ to $26.9 \%$ at $48 \mathrm{~h}$. The ratio of organic-soluble to water-soluble metabolites at $2 \mathrm{~h}$ was $85: 15$ while at $48 \mathrm{~h}$ it was $43: 57$. The results demonstrate that $C$. elegans has the ability to oxidize anthracene in a manner similar to that observed in mammals.
\end{abstract}

\section{INTRODUCTION}

There has been recent interest in the fate of anthracene and its derivatives in the environment since trace amounts are emitted into the environment during coal gasification and liquefaction processes (Blumer, 1976). Although anthracene and its metabolites are not acutely toxic, carcinogenic and/or mutagenic there is a considerable amount of information on the metabolism of these compounds since the anthracene structure is found in carcinogenic polycyclic aromatic hydrocarbons, such as benzo[a]pyrene, benz $[a]$ anthracene and 3-methylcholanthrene.

Micro-organisms with the ability to metabolize anthracene as the sole source of carbon and energy are readily isolated from soil (Gray \& Thornton, 1928; Rogoff \& Wender, 1957; Colla et al., 1958; Evans et al., 1965; Akhtar et al., 1975; Jerina et al., 1976). Bacteria initially oxidize anthracene in the 1,2 position, to form 1,2-dihydro-1,2-dihydroxyanthracene. Jerina et al. (1976) showed that Beijerinckia B-836 and Pseudomonas putida accumulated (+)-cis-1,2-dihydroxy-1,2dihydroanthracene (cis-anthracene dihydrodiol). Further studies have shown that three Pseudomonas strains and a Nocardia strain oxidize cis-anthracene dihydrodiol to 1,2-dihydroxyanthracene. This reaction is catalysed by $(+)$-cis-dihydrodiol dehydrogenase which requires $\mathrm{NAD}^{+}$as an electron acceptor (Patel \& Gibson, 1974). The 1,2-dihydroxyanthracene is further oxidized to ring cleavage products (Evans et al., 1965).

In contrast, mammals metabolize anthracene predominantly in the 1,2 position to form a dihydrodiol with a trans-relative stereochemistry, (Akhtar et al., 1975; Jerina et al., 1976). Evidence has also been presented for an attack at the 9,10-position of anthracene to form 9,10dihydroxy-9,10-dihydroanthracene, 9,10-dihydroxyanthracene, 9,10-anthraquinone, 2,9,10-trihydroxyanthracene and 2-hydroxy-9,10-anthraquinone (Boyland \& Levi, 1935; Boyland \& Shoppee, 1947; Sims, 1964).

Although there have been numerous studies on the bacterial and mammalian oxidation of anthracene, little is known about the metabolism of this compound by fungi. In this report, studies on the fungal metabolism of anthracene are described. 


\section{METHODS}

Organism. Cunninghamella elegans ATCC 36112 was maintained on Sabouraud dextrose agar slants and stored at $4^{\circ} \mathrm{C}$.

Growth conditions and metabolic experiments. Cunninghamella elegans was grown in $125 \mathrm{ml}$ Erlenmeyer flasks which contained $30 \mathrm{ml}$ Sabouraud dextrose broth (Difco). Incubation was carried out at $25^{\circ} \mathrm{C}$ for $48 \mathrm{~h}$ on a rotary shaker operating at $200 \mathrm{rev}$. $\mathrm{min}^{-1}$. After $48 \mathrm{~h}$ the culture broth was filtered and cells of $C$. elegans $(5.9 \mathrm{~g} \mathrm{dry} \mathrm{wt)}$ were resuspended in $30 \mathrm{ml}$ Sabouraud dextrose broth that contained $2.0 \mathrm{mg}$ anthracene dissolved in $0.3 \mathrm{ml}$ dimethylformamide. Six flasks were incubated as described above for $24 \mathrm{~h}$. Control experiments in which anthracene was incubated with Sabouraud dextrose broth in the absence of the organism showed no degradation of the substrate. All flasks were incubated in the dark at $25^{\circ} \mathrm{C}$ for $24 \mathrm{~h}$ as described above. At the end of the experiment, the cultures were examined microscopically for bacterial contamination. No contamination was observed.

After $24 \mathrm{~h}$ the filtrates of each culture broth were pooled and extracted with three equal volumes of ethyl acetate. The combined organic extracts were dried over anhydrous $\mathrm{Na}_{2} \mathrm{SO}_{4}$ and the solvent was removed under vacuum. The residue was examined for metabolic products by TLC and HPLC, and compared to the residue obtained from control experiments.

Experiments with $\left[9-{ }^{14} \mathrm{C}\right]$ anthracene were conducted as described above with the exception that $\left[9-{ }^{14} \mathrm{C}\right] \mathrm{anthra}-$ cene [ $82.5 \mathrm{nmol}, 1.25 \mu \mathrm{Ci}(46 \cdot 25 \mathrm{kBq})]$ in $25 \mu$ limethylformamide was added to each flask. After $0,2,4,8,12,24$ and $48 \mathrm{~h}$ incubation in the presence of $\left[9-{ }^{4} \mathrm{C}\right]$ anthracene, the contents of each flask were filtered and the filtrate was extracted with $6 \mathrm{vol}$. of ethyl acetate. The aqueous layer was extracted until no ethyl acetate soluble radioactivity was detected. The ethyl acetate soluble extracts were combined and the solvent was removed as described above, the residue being analysed by HPLC. Samples $(0.1 \mathrm{ml})$ of the aqueous phase (water-soluble metabolites) were added to $5.0 \mathrm{ml}$ Aquasol-2 and the amount of radioactivity was measured in a liquid scintillation counter.

Analytical methods. Absorption spectra were determined on a Beckman model 25 recording spectrophotometer. TLC was performed with Polygram Sil G/UV254 plastic sheets (Machery-Nagel \& Co., Duren, Germany). Plates were developed in benzene/ethanol $(9: 1, v / v)$. Compounds were visualized by spraying with Gibbs reagent [2,6dichloroquinone-4-chorimide in methanol $(2 \%, w / v)]$ or by viewing under UV light $(254 \mathrm{~nm})$.

A Beckman model 332 high-pressure liquid chromatograph with a model 155-10 absorbance detector operated at $254 \mathrm{~nm}$ was used to separate the anthracene metabolites. $\mathrm{A}_{18}$ Ultrasphere column $(25 \mathrm{~cm} \times 4.6 \mathrm{~mm}$ i.d. $)$ was used for the separation of anthracene metabolites, which was achieved with a programmed 60 min linear gradient of methanol/water $(1: 1$ to $19: 1, \mathrm{v} / \mathrm{v})$. The flow rate was $1 \mathrm{ml} \mathrm{min}{ }^{-1}$. In experiments with $[9-14 \mathrm{C}]$ anthracene, $0.5 \mathrm{ml}$ fractions were collected every $0.5 \mathrm{~min}$ and added to scintillation vials containing $5.0 \mathrm{ml}$ Aquasol-2. The radioactivity present in each fraction was determined in a Beckman LS-250 liquid scintillation counter.

Mass spectra were obtained with a Finnigan model 4023 mass spectrometer at $70 \mathrm{eV}$ ionizing voltage with a solid probe. Direct probe mass spectrometry analyses were performed on samples dissolved in $5 \mu \mathrm{l}$ methanol and dried in glass sample cups. Spectra were recorded as the probe temperature was increased ballistically from 30 to $300{ }^{\circ} \mathrm{C}$, monitoring the ion source temperature at $270{ }^{\circ} \mathrm{C}$. Exact mass measurements were made with a $\mathrm{Kratos}$ MS50 mass spectrometer operating at a nominal resolution of 10000 .

Tests for the relative stereochemistry of the dihydrodiol (cis/trans isomer) were done by dissolving each compound in anhydrous acetone in the presence of anhydrous cupric sulphate; the reaction product was analysed by mass spectrometry (Yang et al., 1977). A positive control of cis-1,2-dihydroxy-1,2-dihydronaphthalene was used.

Deconjugation experiments. Compound II (Fig. 1) was added in equal amounts to three test tubes each containing $5 \mathrm{ml} \mathrm{0.2} \mathrm{M-sodium} \mathrm{acetate} \mathrm{buffer} \mathrm{(} \mathrm{pH} \mathrm{4.5)}$. To one sample $3.0 \times 10^{3}$ Fishman units of $\beta$-glucuronidase (type H-1, Sigma) were added. The second sample was incubated with 15 units of arylsulphatase (Type V, Sigma) and 12.5 $\mu \mathrm{mol} \mathrm{D}$-saccharic acid 1,4-lactone (to inhibit $\beta$-glucuconidase activity). The third sample served as a control and was incubated for $24 \mathrm{~h}$ at $37^{\circ} \mathrm{C}$ on a rotary shaker operating at $150 \mathrm{rev}$. $\mathrm{min}^{-1}$. Samples were then extracted with three equal volumes of ethyl acetate, dried under vacuum at $30^{\circ} \mathrm{C}$ and analysed by HPLC as described above for the separation of anthracene metabolites.

${ }^{18} \mathrm{O}_{2}$ incorporation experiment. Cells of $C$. elegans $\left(30 \mathrm{ml}, 60 \mathrm{mg} \mathrm{dry} \mathrm{wt} \mathrm{ml}{ }^{-1}\right)$ were incubated with anthracene in a $250 \mathrm{ml}$ Erlenmeyer flask modified with a vacuum outlet at its top and with an ${ }^{18} \mathrm{O}_{2}$ bulb (99 atom $\%$ ) fused to the side of the flask. The contents of the flask were degassed with a vacuum pump and by flushing with $\mathrm{N}_{2}$, after which $100 \mathrm{ml}{ }^{18} \mathrm{O}_{2}$ was introduced. The isotopic compostion of the oxygen portion of the atmosphere was monitored during the experiment and was $100 \%{ }^{18} \mathrm{O}^{18} \mathrm{O}$ as measured by mass spectrometry. The trans-1,2dihydroxy-1,2-dihydroanthracene was isolated by HPLC and its isotopic abundance was calculated from the relative intensities of the molecular ions of the ${ }^{16} \mathrm{O}$ and ${ }^{18} \mathrm{O}$ species at $m / e 212,214$ and 216 , respectively, on a Finnigan model 4023 mass spectrometer.

Chemicals. Anthracene was obtained from Aldrich Chemical Co., Milwaukee, Wis., U.S.A. $\left[9-{ }^{14}\right.$ C]Anthracene 


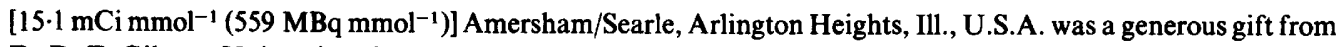
Dr D. T. Gibson, University of Texas at Austin, Tex., U.S.A. Solvents for HPLC were purchased from Burdick and Jackson Laboratories, Muskegon, Mich., U.S.A. All other chemicals were of reagent grade or the highest available purity.

\section{RESULTS}

Mycelial pellets of C. elegans were incubated with anthracene in Sabouraud dextrose broth for $24 \mathrm{~h}$. TLC analysis of the organic solvent-soluble metabolites revealed the presence of anthracene $\left(R_{F} 0.61\right)$ and two oxidation products $\left(R_{F} 0.08\right.$ and $\left.0 \cdot 12\right)$. HPLC analysis of the metabolites formed during anthracene oxidation is shown in Fig. 1. The two major compounds were almost certainly anthracene metabolites since they did not appear in control samples. The absorption spectrum of compound I and its acid catalysed dehydration product is shown in Fig. 2. The UV spectral properties of compound I are identical to those reported for trans-1,2-dihydro-1,2dihydroxyanthracene (Jerina et al., 1976). Furthermore, the acid catalysed dehydration of compound I (Fig. 2) produced a phenol whose spectral and chromatographic properties are similar to 1-anthrol (Sims, 1964). HPLC analysis of the dehydration products indicated that compound I was converted to a mixture of 1-anthrol and 2-anthrol. A similar experiment with 9${ }^{14} \mathrm{C}$-labelled compound I indicated that the ratio of 1 -anthrol to 2 -anthrol was $86: 14$. Mass spectral analysis of compound I (Fig. 3) showed a molecular ion at $m / e 212$, and the loss of $\mathrm{H}_{2} \mathrm{O}$ $\left(\mathrm{M}^{+}-18\right)$ from the molecular ion gave an ion at $m / e$ 194, which is indicative of a dihydrodiol. This molecular composition was confirmed by high-resolution mass measurement (calculated for $\mathrm{C}_{14} \mathrm{H}_{12} \mathrm{O}_{2}, 212.0837$; observed, 212.0839). Although the absorbance and mass spectral data indicated that $C$. elegans formed 1,2-dihydro-1,2-dihydroxyanthracene, the data do not provide evidence for the relative stereochemistry of the hydroxyl groups. The trans-stereochemistry of compound I was assigned on the basis of its relative stability in acid compared to that reported for the cis-isomer (Jerina et al., 1976). In addition, compound I gave a negative response when tested with potassium triacetylosmate (Criegee et al., 1942) and did not form an acetonide (Yang et al., 1977). Moreover, all dihydrodiols produced by $C$. elegans have been shown to have a transrelative stereochemistry (Cerniglia, 1981). Further evidence was provided by an ${ }^{18} \mathrm{O}_{2}$ experiment in which $C$. elegans was grown in the presence of anthracene under ${ }^{18} \mathrm{O}_{2}$ for $24 \mathrm{~h}$ and the anthracene metabolites isolated by HPLC. The trans-1,2-dihydroxy-1,2-dihydroanthracene formed in the presence of ${ }^{18} \mathrm{O}_{2}$ was isolated; mass spectral analysis showed a molecular ion at $m / e 214$, indicating that one of the oxygen atoms of the dihydrodiol is derived from molecular oxygen.

The UV absorption spectrum $\left(\lambda_{\max } 252 \mathrm{~nm}\right)$ of the second metabolite, compound II, is shown in Fig. 4. TLC analysis of compound II in benzene/ethanol $(9: 1)$ showed the presence of a single spot with an $R_{F}$ value of 0.08 . These data indicate that compound II is a very polar metabolite. Since previous studies have shown that $C$. elegans has the ability to form glucuronide and sulphate conjugates of aromatic hydrocarbons (Cerniglia \& Gibson, 1979; Dodge et al., 1979) an experiment was done in which compound II was incubated with arylsulphatase and/or $\beta$ glucuronidase. Separation of the metabolites released after enzyme treatment by HPLC indicated that enzymic hydrolysis of compound II with arylsulphatase, but not with $\beta$-glucuronidase, released a compound which eluted at the same HPLC retention time $(32.5 \mathrm{~min})$ as 1 -anthrol. Mass spectral analysis of the hydrolysis product gave a molecular ion at $m / e 194$, which indicated that compound II was a sulphate ester of 1-anthrol. The non-hydrolysed control sample showed no release of ethyl acetate-soluble products.

The metabolism of $\left[9-{ }^{14} \mathrm{C}\right] \mathrm{anthracene}$ in cells of $C$. elegans was determined by measuring the amount of radioactivity in the ethyl acetate and water phases of the culture filtrate after $2,4,8$, 12,24 and $48 \mathrm{~h}$ incubation. The ethyl acetate soluble metabolites were separated and quantified by HPLC. Approximately $84 \%$ of the added $\left[9-{ }^{14} \mathrm{C}\right]$ anthracene was recovered from each incubation flask and $21 \%$ of the total radioactivity added adhered to the mycelia and was found to be mainly non-utilized anthracene. The results in Table 1 show that the total amount of [9${ }^{14} \mathrm{C}$ lanthracene metabolized increased from $2.0 \%$ at $2 \mathrm{~h}$ to $26.9 \%$ at $48 \mathrm{~h}$. The compounds trans- 


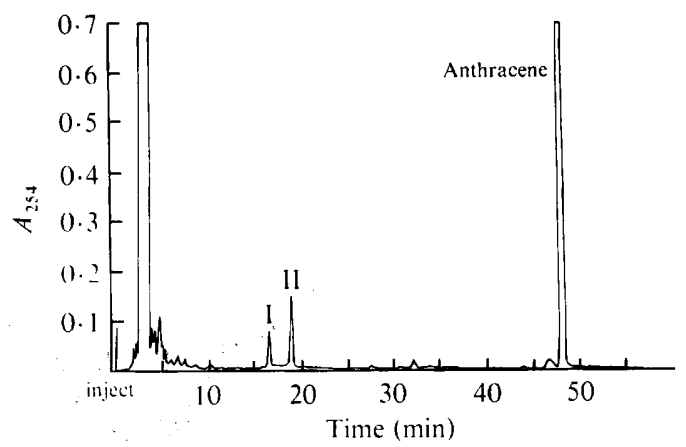

Fig. 1. HPLC elution profile of ethyl acetate-soluble metabolites formed from anthracene by $C$. elegans. HPLC conditions were as described in Methods. I represents compound I, and II, compound II.

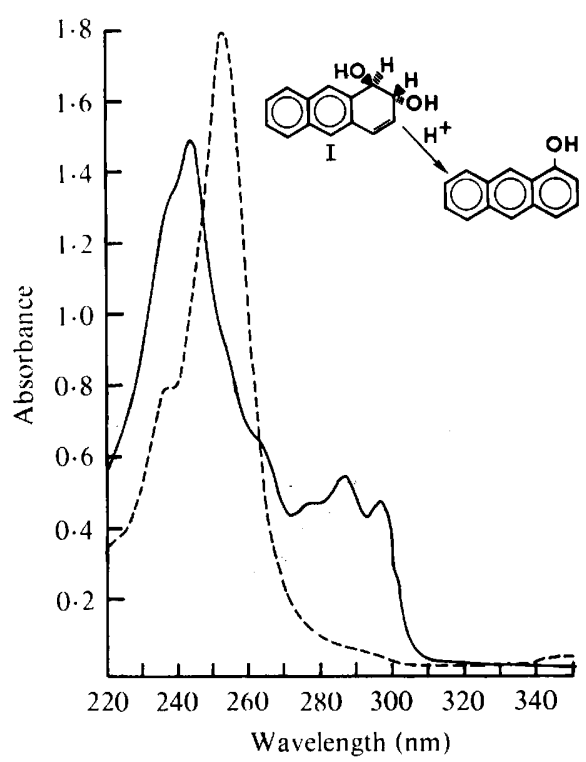

Fig. 2

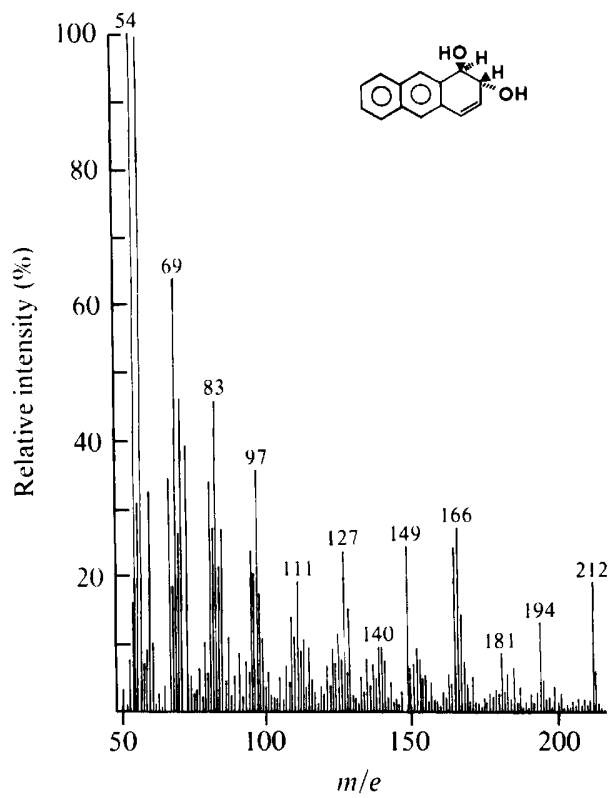

Fig. 3

Fig. 2. Absorption spectra of Compound I. Spectra were recorded on a Beckman model 25 recording spectrophotometer before acid and heat treatment (-), and after acid treatment with $6 \mathrm{M}-\mathrm{HCl}$ and boiling in water for $15 \mathrm{~min}(----)$.

Fig. 3. Mass spectrum of compound I.

1,2-dihydroxy-1,2-dihydroanthracene and 1-anthryl sulphate accounted for $42 \%$ and $27 \%$, respectively, of total metabolites after $4 \mathrm{~h}$ incubation of $\left[9-{ }^{14} \mathrm{C}\right]$ anthracene with cells of $C$. elegans. After longer incubation ( $48 \mathrm{~h}$ ), the ratio of ethyl acetate-soluble to water-soluble metabolites decreased: at $2 \mathrm{~h}$ it was $85: 15$ while at $48 \mathrm{~h}$ it fell to $42 \cdot 7: 57 \cdot 3$ (Table 1). The large amount of [9${ }^{14} \mathrm{C}$ ]anthracene water-soluble metabolites is in accord. with previous studies on the fungal metabolism of benzo[a]pyrene (Cerniglia \& Gibson, 1979). These metabolites may be polyhydroxylated anthracene metabolites and/or their sulphate and glucuronide derivatives. 


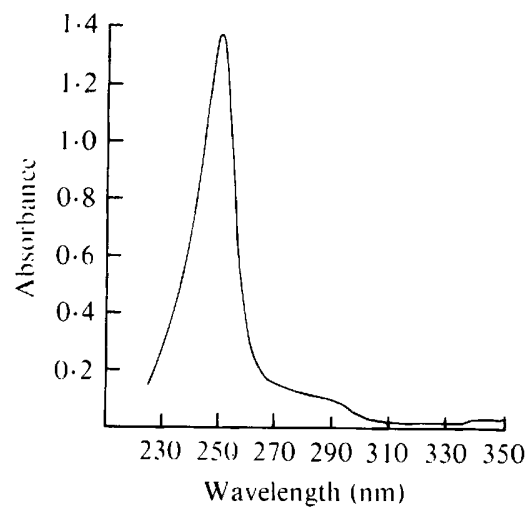

Fig. 4. Absorption spectrum of compound II.

Table 1. Distribution of radioactivity of metabolites formed from $\left[9-{ }^{14}\right.$ C]anthracene by $C$. elegans

\begin{tabular}{|c|c|c|c|c|c|}
\hline \multirow[b]{3}{*}{$\underset{\text { (h) }}{\text { Time }}$} & \multirow[b]{3}{*}{$\begin{array}{c}\text { Total } \\
\text { metabolism }(\%)\end{array}$} & \multicolumn{4}{|c|}{ Percentage distribution of metabolites } \\
\hline & & \multirow[b]{2}{*}{$\begin{array}{l}\text { Water } \\
\text { soluble* }\end{array}$} & \multicolumn{3}{|c|}{ Ethyl acetate soluble $\dagger$} \\
\hline & & & $\begin{array}{l}\text { trans-1,2-Dihydroxy- } \\
\text { 1,2-dihydroanthracene }\end{array}$ & 1-Anthryl sulphate & Total \\
\hline 2 & $2 \cdot 0$ & 0.3 & 0.8 & 0.3 & 1.7 \\
\hline 4 & $8 \cdot 8$ & 1.9 & 3.7 & $2 \cdot 4$ & 6.9 \\
\hline 8 & $11 \cdot 4$ & 4.0 & 3.7 & $2 \cdot 0$ & $7 \cdot 4$ \\
\hline 12 & $15 \cdot 7$ & $6 \cdot 2$ & $3 \cdot 3$ & $1 \cdot 8$ & $9 \cdot 5$ \\
\hline 24 & $21 \cdot 3$ & $9 \cdot 8$ & $2 \cdot 5$ & 1.8 & $11 \cdot 5$ \\
\hline 48 & 26.9 & $15 \cdot 4$ & $2 \cdot 2$ & $1 \cdot 8$ & $11 \cdot 5$ \\
\hline
\end{tabular}

* Radioactivity recovered from the aqueous phase of the media after ethyl acetate extraction, expressed as percentage of added radioactivity.

† Radioactive ethyl acetate-soluble metabolites were determined by HPLC as described in Methods.

\section{DISCUSSION}

The results presented here show that $C$. elegans can oxidize anthracene. The metabolic scheme for the oxidation of anthracene by $C$. elegans is given in Fig. 5. The predominant metabolite formed was trans-1,2-dihydroxy-1,2-dihydroanthracene. The formation of a dihydrodiol with a trans-relative stereochemistry, and the ${ }^{18} \mathrm{O}_{2}$ experiment which indicated that one atom of oxygen was incorporated into the trans-1,2-dihydroxy-1,2-dihydroanthracene, suggest a mono-oxygenase catalysed reaction and the prior formation of anthracene-1,2-oxide (Daly et al., 1972; Fu et al., 1978). The metabolite trans-1,2-dihydroxy-1,2-dihydroanthracene could be formed from initial epoxidation of the 1,2 double bond of anthracene, followed by an epoxide hydrolase catalysed hydration to form the dihydrodiol. Recently it has been shown that cell extracts prepared from $C$. elegans have epoxide hydrolase activity (Wackett \& Gibson, 1981). 1-Anthrol may arise by spontaneous isomerization of anthracene 1,2-oxide or by a direct insertion mechanism. The enzymic mechanism for the oxidation of anthracene is similar to that described for the fungal metabolism of naphthalene (Cerniglia \& Gibson, 1977, 1978; Cerniglia et al., 1978).

Similar results have been reported in mammals where the mono-oxygenase-epoxide hydrolase enzyme systems oxidize anthracene almost entirely to trans-1,2-dihydroxy-1,2-dihydroanthracene. The compounds 1 - and 2 -anthrol are minor oxidation products since anthracene 1,2oxide has been shown to be relatively resistant towards isomerization to phenols, and to be a good substrate for epoxide hydrolase (Akhtar et al., 1979). It will be interesting to see if the purified fungal epoxide hydrolase also has high specificity with respect to anthracene 1,2-oxide. 

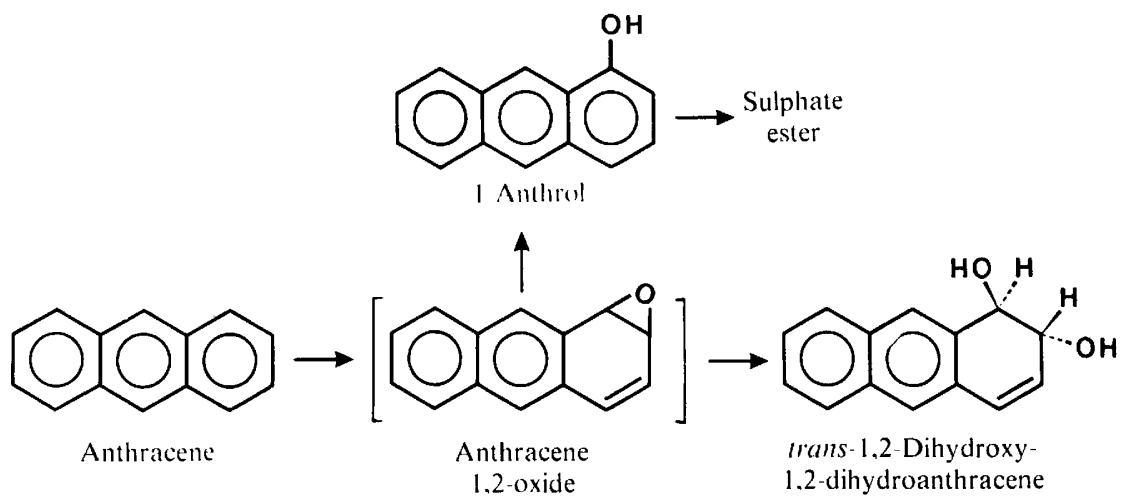

Fig. 5. Proposed pathway for the metabolism of anthracene by C. elegans. The compound in brackets was not isolated. Absolute stereochemistry is not implied.

1-Anthryl sulphate was also formed from anthracene by $C$. elegans. Sulphate conjugation reactions in mammals are thought to be important as detoxification mechanisms, but the role and enzymic basis of this reaction in fungi has yet to be determined.

It is clear from these results that $C$. elegans has the capacity to oxidize anthracene. Further investigation of the mechanism of anthracene hydroxylation and the role of enzymes involved in the metabolism of anthracene is evidently warrented.

The author greatly appreciates the technical assistance of Kim Davis, Michael Fox and of Dr J. P. Freeman in obtaining the mass spectra reported.

\section{REFERENCES}

AkhtaR, M. N., Boyd, D. R., ThOmpson, N. J., Koreeda, M., Gibson, D. T., Mahadevan, V. \& JERINA, D. M. (1975). Absolute stereochemistry of the dihydroanthracene-cis and trans-1,2-diols produced from anthracene by mammals and bacteria. Journal of the Chemical Society, 2506-2511.

AkhtaR, M. N., Hamilton, J. G., Boyd, D. R., Braunstein, A., Seifried, H. E. \& Jerina, D. M. (1979). Journal of the Chemical Society - Perkin Transactions I, 1442-1446.

BLUMER, M. (1976). Polycyclic aromatic hydrocarbons in nature. Scientific American 234, 34- 44.

Boyland, E. \& Levi, A. A. (1935). Production of dihydroxydihydroanthracene from anthracene. Biochemical Journal 29, 2679-2683.

Boyland, E. \& SHOPPEE, C. W. (1947). The metabolism of polycyclic compounds. The configuration of the dihydroxydihydroanthracene produced from anthracene. Journal of the Chemical Society, 801-804.

Cerniglia, C. E. (1981). Aromatic hydrocarbons: metabolism by bacteria, fungi and algae. In Reviews in Biochemical Toxicology 3, pp. 321-361. Edited by E. Hodgson, J. R. Bend \& R. M. Philpot. New York: Elsevier/North Holland.

Cerniglia, C. E. \& Gibson, D. T. (1977). Metabolism of naphthalene by Cunninghamella elegans. Applied and Environmental Microbiology 34, 363-370.

CERniglia, C. E. \& Gibson, D. T. (1978). Metabolism of naphthalene by cell extracts of Cunninghamella elegans. Archives of Biochemistry and Biophysics 186, 121-127.
Cerniglia, C. E. \& Gibson, D. T. (1979). Oxidation of benzo[a]pyrene by the filamentous fungus Cunninghamella elegans. Journal of Biological Chemistry 254, 12174-12180.

Cerniglia, C. E., Herbert, R. L., Szaniszlo, P. J. \& Gibson, D. T. (1978). Fungal transformation of naphthalene. Archives of Microbiology 117, 135-143.

Colla, C., Fiecchi, A. \& Treccani, V. (1958). Richerche sul metabolismo ossidativo microbico dell' anthracene e del fenanthrene. Annales de microbiologie 9, 87-91.

Criegee, R., Marchand, R. \& Wannowius, H. (1942). Organic osmium compounds. II. Mitteilung. Annals of Chemistry 550, 99.

DALY, J. W., Jerina, D. M. \& WitKoP, B. (1972). Arene oxides and the NIH shift: the metabolism, toxicity and carcinogenicity of aromatic compounds. Experientia 28, 1129-1149.

Dodge, R. H., Cerniglia, C. E. \& Gibson, D. T. (1979). Fungal metabolism of biphenyl. Biochemical Journal 178, 223-230.

Evans, W. C., Fernley, H. N. \& Griffith, E. (1965). Oxidative metabolism of phenanthrene and anthracene by soil pseudomonads. The ring fission mechanism. Biochemical Journal 95, 819-831.

Fu, P. P., Harvey, R. G. \& Beland, F. A. (1978). Molecular orbital theoretical prediction of the isomeric products formed from reactions of arene oxides and related metabolites of polycyclic aromatic hydrocarbons. Tetrahedron 34, 857-866.

GRAY, H. H. P., \& THORNTON, H. G. (1928). Soil bacte- 
ria that decompose certain aromatic compounds Zentralblatt für Bakteriologie, Parasitenkunde, Infectionskrankheiten und Hygiene 73, 74-96.

Jerina, D. M., Selander, H., Yagi, H., Wells, M. C., DaveY, J. F., Mahadevan, V. \& Gibson, D. T. (1976). Dihydrodiols from anthracene and phenanthrene. Journal of the American Chemical Society 98, 5988-5996.

Patel, T. R. \& Gibson, D. T. (1974). Purification and properties of (+)-cis-naphthalene dihydrodiol dehydrogenase of Pseudomonas putida. Journal of Bacteriology 119, 879-888.

Rogoff, M. N. \& WeNDER, J. (1957). 3-Hydroxy-2naphthoic acid as an intermediate in the bacterial dissimilation of anthracene. Journal of Bacteriology 74, 108-109.
Sims, P. (1964). The metabolism of anthracene and some related compounds in rats. Biochemical Journal 92, 621-631.

WACKETT, L. P. \& GIBSON, D. T. (1981). Metabolism of xenobiotic compounds by fungal enzymes. 81 st Annual Meeting of the American Society for Microbiology, p. 163.

YANG, S. K., McCourt, D. W., GelboIn, H. V., Miller, J. R. \& Roller, P. P. (1977). Stereochemistry of the hydrolysis products and their acetonides of two stereoisomeric benzo(a)pyrene 7,8-diol 9,10-epoxides. Journal of the American Chemical Society 99, 5124-5129. 